\title{
Correction: Rhegmatogenous retinal detachment: a review of current practice in diagnosis and management
}

Sultan ZN, Agorogiannis EI, Iannetta D, et al. Rhegmatogenous retinal detachment: a review of current practice in diagnosis and management. BMJ Open Ophthalmol 2020;5:e000474. doi: 10.1136/bmjophth-2020-000474

This article was previously published with errors:

Figure 1 caption 'Retinal detachment. Left eye, superior bullous retinal detachment' has been corrected to 'Retinal detachment. Left eye, superior bullous retinal detachment. Reproduced with permission of Wills Eye Hospital, WillsEye.org'.

Figure 4 was incorrect. The correct figure is shown below:

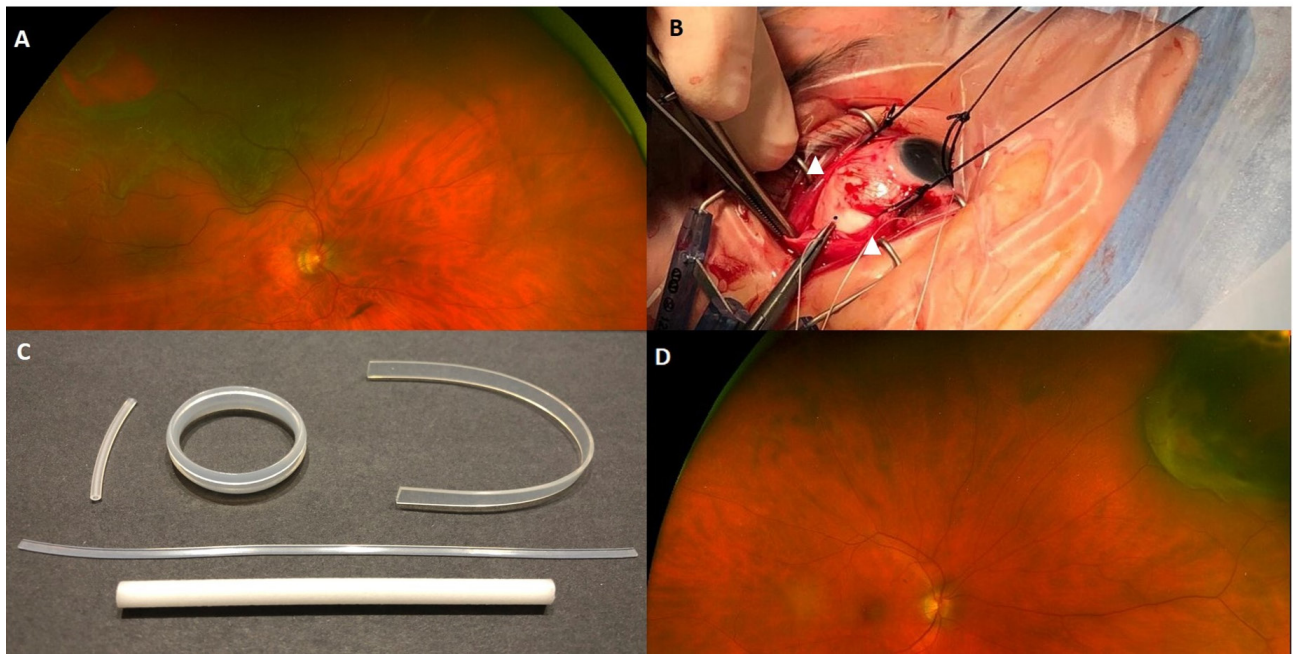

Figure 5 caption 'Pars plana vitretomy. Three ports—an infusion line, a light source and a vitrector.' has been corrected to 'Pars plana vitretomy. Three ports—an infusion line, a light source and a vitrector. Reproduced with permission of PentaVision LLC, https://www.retinalphysician.com/issues/2008/jan-feb/why-(and-when)-i-prefer-25g-vitrectomy'

Open access This is an open access article distributed in accordance with the Creative Commons Attribution Non Commercial (CC BY-NC 4.0) license, which permits others to distribute, remix, adapt, build upon this work non-commercially, and license their derivative works on different terms, provided the original work is properly cited, appropriate credit is given, any changes made indicated, and the use is non-commercial. See: http://creativecommons.org/licenses/by-nc/4.0/.

(c) Author(s) (or their employer(s)) 2021. Re-use permitted under CC BY-NC. No commercial re-use. See rights and permissions. Published by BMJ.

BMJ Open Ophth 2021;6:e000474corr1. doi:10.1136/bmjophth-2020-000474corr1

Check for updates 